\title{
生体におけるレーザ応用
}

\section{II .レーザラマン分光法による眼組織の解析}

キーワード

ラマン分光法, 水晶体, 角膜, 強膜, 視神経, 近赤外レーザ, スペクトル解析
水 野 有 武

慈恵医科大学・医化学教室

\section{1.はじめに}

眼は視覚に関する感覚器である。それ沛之光を通し, 屈 折させ，調節して焦点を網膜に合わせるという機能に適応 した，特殊な組織構造を有する。すなわち，図10よう に, 最初に光が入る角膜, 房水を通り最大の屈折力のある 水晶体，ゲル状の硝子体は透明組織であり，そして網膜は 光の受容器であり，大脳と同じ中枢神経の性質を有してい る。カメラと同じくよけいな光が入らないように，眼には 暗箱となる組織あがる。虹彩，ぶどう膜である。眼球はそ の名のと扝り球形でゴムまりのような構造で硬い膜が外壁 をなす。前面の透明組織である角膜に続く，不透明白色を した強膜がある。それに暗箱のブドウ膜に乗るように眼底 に張り付いている網膜と，そこから情報を大脳中枢に伝え る神経線維の束である視神経などである。このように眼組 織㹥その性質上，高度に分化した組織とそれを支えるのに 特殊化した多種な組織から欈成されており，ラマン分光法 を生体に応用するとき，いろいろな角度からラマン分光法 の有用性と不利な点を検討できる組織がそろっている。

前揭の尾崎の総説にもあるように(1)，レーザラマン分光 の測定法は近年のレーザの発達と検出法の発達により数多 くの方法が開発されてきた。生態組織に応用する場合はそ れらの測定特性を考えて適用する必要がある。従来の分散 型の可視光励起のラマン分光法では生体組織の不透明性, 加齢や病的変化て增える蛍光物質，レーザ光そのものによ る生体物質の变化, 变性などの不利な点が多々ある。生体 組織で比較的ラマン測定しやすいのは，それ自身が透明で 可視光をよく通し, 蛋白質濃度が高い水晶体である。同じ 透明組織でも角膜は，蛋白質濃度があまり高くなく1ミリ メートル以下と薄いので測定しにくい。それに不透明であ る強膜や視神経は測定不可能に近い。測定しやすい水晶体 でもヒトのそれは小睍のものでもかなりの蛍光の妨害で測 定は不可能に近い。まして病的な白内障水晶体では蛍光物 質の蓄積が増加するため測定は不可能であった。

そこで，ラマンスペクトルをこれらの生体組織から測定 するため, 近赤外レーザ光を使い生体に多い蛍光の影響を 除外し,さらにフーリエ変換することで短時間で高感度の 測定ができる近赤外励起 (NIR)-フーリ工変換 (FT) ラ マン分光法応用すると測定は可能となった。

Laser Application for Biomaterials.

II. Laser Raman specctroscopic analysis of ocular tissues

by Aritake Mizuno (Jikei University)

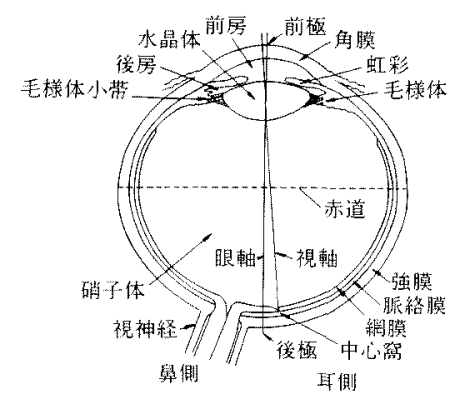

図 1 眼球の水平断面図

そこで, 今回は, 従来からよく行われてきた水晶体の研 究をまず取り上げる。次に, 角膜, 強調, そして最後に視 神経と順に生体の生のままのラマンスペクトル測定法と生 体結合組織の構成成分である精製コラーゲンのラマンスペ クトルを供覧する。

\section{2. 水晶体のラマンスペクトル}

水晶体は眼球の中, 前方に位固し, 文字どうりレンズと して見えるものの焦点を網膜に合わせて投影する役をして いる。毛様体筋の力を借りて, 水晶体の柔軟性をもとに, 自ら膨らんだり偏平になったりして調節を行う。

水晶体は基底膜をなすセロファンのように薄い水晶体露 により囲まれた, 透明な無血管の器官である。有核の細胞 は前謽下に一層に並ぶ上皮細胞のみで，前湾曲の周辺に位 置する增殖带で分裂した細胞は水晶体震に添って後方へ移 動していく。ちょうど赤道部を過ぎたところで分化をはじ め, 水晶体繊維として前後方向へ伸展していく。そして, 外加ら巻きつくうに延びてきて, 前後両方向から纎維が 会合するところで, 水晶体の縫合を生じる（図2）。伸展 した水晶体瀻維は, 赤道部より少し入った水晶体湾曲部 (Lens Bow) で水晶体特有の細胞脱核を起こしてくる。

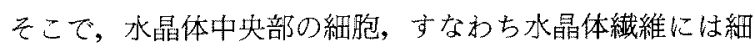
胞核がない。絶えず新生した水晶体瀻維は周りから巻くよ うにして水晶体は大きくなっていく。一生の間絶えず新生 しているので，水晶体はどんどん大きくなっていくわけで ある。人生 80 年の間大きくなるとすると, 眼球いっぱい になってしまうであろう。しかし，そうはならない機構が 存在する。水晶体の中心部では, 脱水すなわち水晶体蛋白 質を濃縮して硬い水晶体核を形成して，体積があまり増え ないようにしている。老眼になるのはこの硬い水晶体核が できるため，水晶体の柔軟性による調節力が落ちるためで 


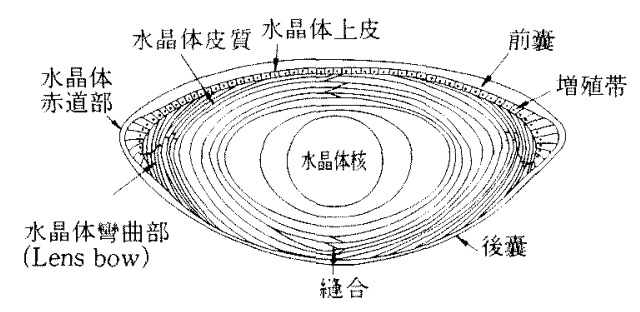

図 2 水晶体の断面図

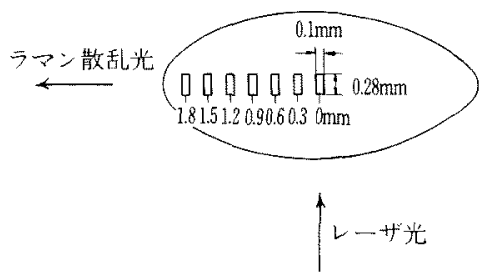

図 3 水晶体の局所的微細部位からのラマンスペクト ル測定法

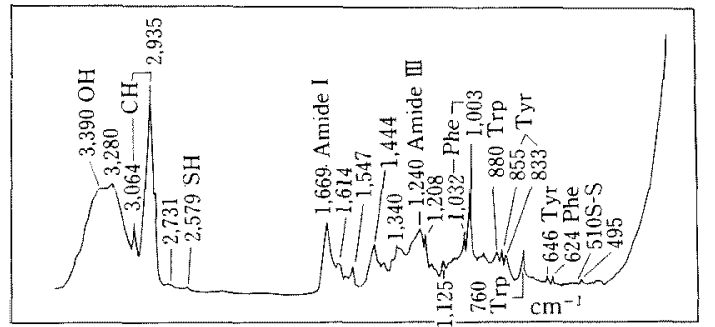

$514.5 \mathrm{~nm}$ アルゴンレーザで励起。横軸は波数 (wave number, $\mathrm{cm}^{-1}$ )，綐 朝はラマン強度。

図 4 ラット水晶体中心部から全領域ラマンスペクトル

ある。

逆に水晶体核の中心には，水晶体で一番古い組織が残つ ていることになる。水晶体が発生したときの一次㵶維の組 織成分が残っているのである。水晶体は構造上無血管で, 中心にいく活ど代謝は極めて弱いので，古い組織が残る。 増殖帯から赤道部にかけては, 分裂したてで, 分化を始め たばかりの本当に若い細胞と, 胎生期の発生の初期からの 本当に年取った細胞が，この水晶体という小宇宙のなかに トポロジカルに共存しているのである(2)。

ラット水晶体を傷つけずそのまま取り出して, 四方石英 ガラスのセルの中の器官培着メジウム中に入れる。こうす ると数日間は眼球中にあるままの状態を保つことができ る。そして，図 3 のように下方よりレーザ光を当て，90 の方向でラマン散乱光を分光器に導いて測定する。ラット の正常水晶体の中心から測定したラマンスペクトルの全領

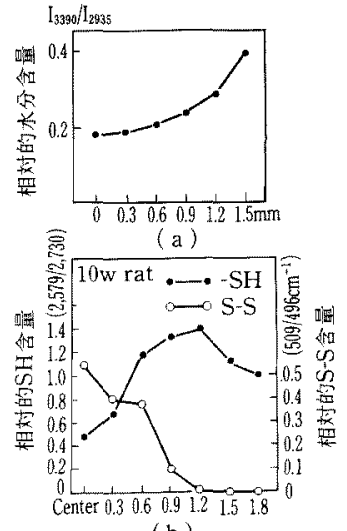

(b)

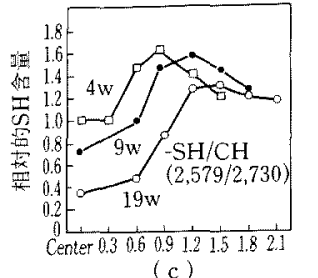

図3の方法を用いた (a)相対水分含量 (b)相対 SHとS-S含量 (c)相対 $\mathrm{SH}$ 含显の加路变化 (週齿)

図 5 中心からの水平端への距離

域を図 4 に示す。ピークとして現われるバンドは，主とし て水晶体蛋白質からのもので, $1,003 \mathrm{~cm}^{-1}$ にはフェニール アラニンのベンゼンリングの伸縮振動によるピークが $1,240 \mathrm{~cm}^{-1}$ にアミドIII， $1,669 \mathrm{~cm}^{-1}$ にはアミドIによるバ ンドが現われる。このアミドの位置により，水晶体蛋白質 の二次構造は逆平行 $\beta$ 構造であることがわかる。

$3,390 \mathrm{~cm}^{-1}$ には OH の伸縮振動によるバンドが現われ， 水晶体ではほとんど水の $\mathrm{OH}$ からのもので, 測定部位の 相対水分含量を示すことができる。2,579 $\mathrm{cm}^{-1} と 509$ $\mathrm{cm}^{-1}$ には，生体還元物質となる主に蛋白質の SH 基とそ の酸化された状態のS-S 結合を表すバンドが観察される。 この三つのマーカを使うと，水晶体核の形成状態をみるこ とができる。水晶体内の局所的な水の分布図 $5 \mathrm{a}$ と $\mathrm{SH}$ 基, $\mathrm{SS}$ 結合分布を図 $5 \mathrm{~b}, \mathrm{c}$ に示す ${ }^{(3)}$ 。相対的な水分含传 は $\mathrm{OH}$ の伸縮振動のバンドの強度 $\mathrm{I}_{3395}$ と蛋白質の $\mathrm{CH}$ の 伸縮振動のバンドの強度 $\mathrm{I}_{2935}$ との比 $\mathrm{I}_{3395} / \mathrm{I}_{2935}$ で表せる。 $\mathrm{SH}$ 基の相対含量は $\mathrm{I}_{2579} / \mathrm{I}_{2731}$ で, SS 結合のそれは $\mathrm{I}_{509} / \mathrm{I}_{495}$

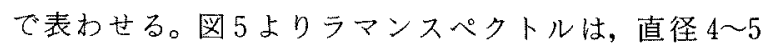
$\mathrm{mm}$ というラット水晶体の局所的な部位からの分子レ心゙ ルの情報を，しかも水晶体は生きたままの非破壇状態で得 ら机る。水晶体の中心は水分が少なく，そのぶん蛋白質濃 度が高く，周辺の赤道部にいくにしたがい水分が多く，蛋 白質濃度が低いという結果になっている。SH 基は水晶体 中心が低く，だんだんと周辺にいくにしたがい相対含量は 高くなり，そして赤道部近くでまた下がる。水晶体瀻維の 成長と加踰を示している。SS 結合の相対含量は中心部が 
一番高く，周辺にいくにしたがい急速に低下する。ちょう ど水晶体核の形成された部位と一致している。一つの水晶 体の結果からも，水晶体核の形成には脱水現象とSH 基 のSS 結合への変換，すなわち酸化が関係していることが 分かる。一番年をとった古くからある部分のSS 結合の量 が一番多く、一番酸化されていることになる。

加齢による変化をラット水晶体中心，すなわち核の中心 で測定した結果，水分および $\mathrm{SH}$ 基相対含量は加齢と共 に最初は急に，そしてだんだんと緩やかになりながらも減 少していることがわかった。水晶体の中心部は加苓ととも に, 脱水現象を示すように水分含量が減る。この現象は $\mathrm{SH}$ 基の減少と SS 結合の増加と極めてょく相関する。図 6 に水分 $\mathrm{I}_{3395} / \mathrm{I}_{2935}$ と SH 基 $\mathrm{I}_{2579} / \mathrm{I}_{2731}$ の相対含量の相関を グラフにするとよい相関を示す(4)。水晶体核の形成に，脱 水すなわち蛋白質の濃縮と SH 基の SS 結合への変換が大 きな役割をしていることがわかる。いいかえると，蛋白質 のSH 基が SS 結合に酸化されて変換することにより，蛋 白䝷の巨大分子化して，水晶体核の形成に結びつくのであ ろう。

加齢変化としてラマン分光学で捉えられる上に述べな以 外の変化として，チロシンとトリプトファンの微環境の変 化である。キロシンとトリプトファンとも $700 〜 900 \mathrm{~cm}^{-1}$ に2 本のバンドがあり，それぞれの强度比 $\mathrm{I}_{833} / \mathrm{I}_{855}$ と $\mathrm{I}_{880} /$ $I_{760}$ を測定する。チロシンは加齢では，わずかしか変化し ないが，トリプトファンは加歯とともに，蛋白質に埋もれ ていたものが，表面に露出されてくるということであ

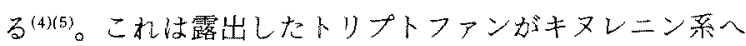
変化して，加齢とともに增える着色物質や蛍光物質の蓄積 につながる変化と思われる。これら加齢変化は生理的変化 である。次に水晶体の病的変化についてラマン分光で検索 してみる。

水晶体の病的変化の場合，ほとんど水晶体は白濁化して くる。ほとんどが水晶体蛋白質の変性を伴うからで，その ように白濁した水晶体を白内障と呼ぶ。加えに，白内障は 一つの症候群ともいうべきもので，原因はさまざまであ り，むしろ原因不明のことが多い。ラマン分光学により得 られた知見は, 病的変化としての白内障の変化は, 加菊変

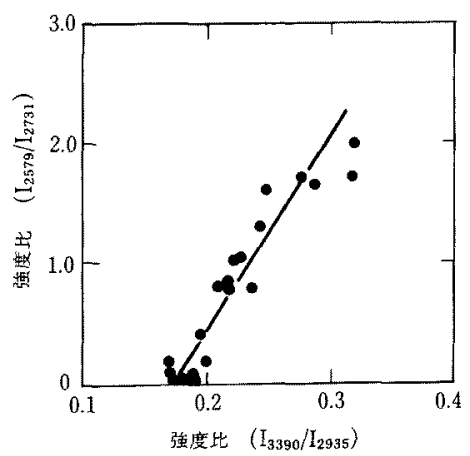

図 6 ラット水晶体の $\mathrm{SH}$ 基と水分含量の相関
化が病的状態で加速されたものであるといえるが，水晶体 の水分含量だけは加跲変化と逆である。その例を求にあげ る。

白内障化のラマン分光法で捉えられる変化は加齢変化が 促進されることが多い。その例を二，三西げる。中野マウ スは先天性の白内障マウスである。生後 3 週目に水晶体の 中心より混溜を生じる。ラマン分光法により検索すると, 図 7 に示すように，加齢現象が促進されたごとく，SH 碁 は混濁が始まるとともに急速に減入する。チロシンは混濁 と共に蛋白質のなかに埋もれていくという变化を示す。逆 にトリプトファンは加龄変化が促進されるように，蛋白質 から顔をだして光化学变化を受けやすくなっている。しか し，水分含有量は白濁化と共に增加して，糖尿病の時とお なじく加莑変化とは逆である。白内障になると水晶体の仡 オンバランスがくずれて，水分含量は増えるのは当然であ ろう。蛋白質が相転移を㧍こすとき，チロシンが会合した 蛋白質のなかに埋もれる現象を捉えていると思われる。
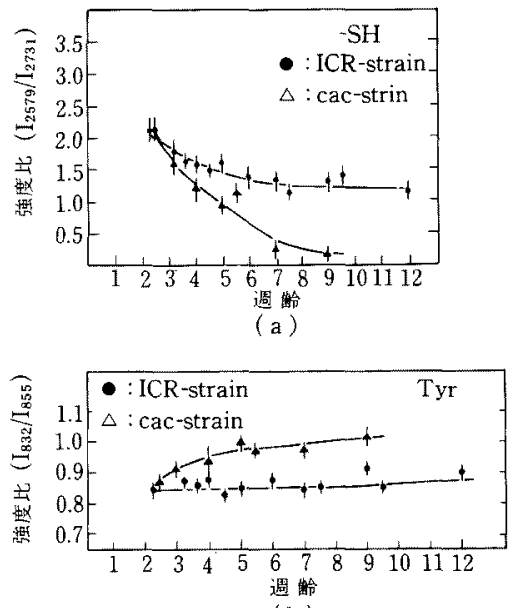

(b)
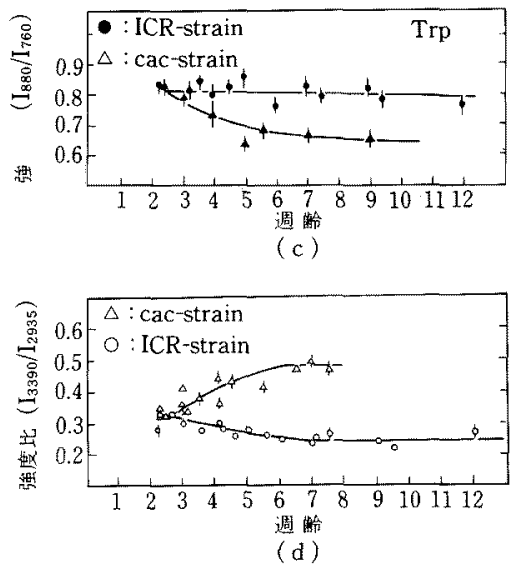

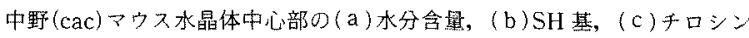
残基と（d）トリフトトファン残基の微罢境変化

図 7 先天性白内障マウス 


\section{3. ヒト水晶体のラマンスペクトル}

次に測定したいのは当然ヒトの水晶体である。七トの水 晶体は白内障の手術のとき得ら机ることが多い。白内障患 者が比較的高萪なこともあり白濁しておりラマン測定を妨 害する蛍光が極めて強く, 従来型の分散型ラマン分光器で は測定不可能に近い。Yuらが行った研究を図 8 で示す と, 蛍光は年令と励起するレーザ光の波長に大きく左右さ 机る ${ }^{(6)}$ 。14才の正常水晶体で $\lambda$ critical は $514.5 \mathrm{~nm}$ でそ れより短い波長のレーザ光では蛍光の影響が大きく過ぎて うまく測定できない。それより長波長がわでは測定可能で ある。特に $1,000 \mathrm{~nm}$ 位の近赤外の励起波長ではほとんど 监光がでないことが予测される。

この蛍光の妨害を極力うけずにきれいなスペクトルを測 定する方法にはいくつかあるが，従来型の可視光励起のラ マン分光器で測定したGijsbersらがいる。彼らは $1 \%$ パラ フォルムアルデヒドで固定した後 $514.5 \mathrm{~nm}$ のレーザ光で 10 から 24 時間照射し, 内在性の蛍光物質を光破壊して加 らラマンスペクトルを測定した。図 9 はその一例である。 33 才の水晶体で 16 時間レーザ照射後スペクトル測定して

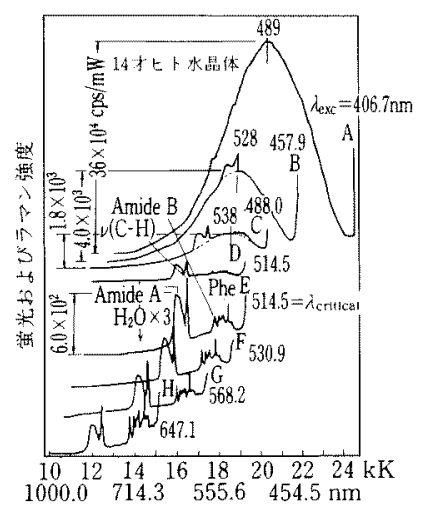

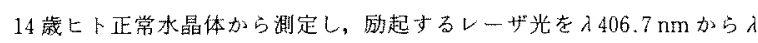
$647.1 \mathrm{~nm}$ まで各種変えている。波長の短いレ一ザ光のほうが蛍光を耐起し

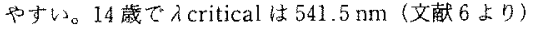

図 8 虽光とラマンスペクトルの競合関俰
いる。水晶体の白濁した部分（右）と白潈していない部分 (左) から測定している。

このように苦労しなくとも容易にヒト水晶体から測定で きる方法が, 前揭の総説にある近赤外励起(NIR)-フーリ 工変換 $(\mathrm{FT})$ ラマン分光法である。図 10 に示すような方法 で測定する。サンプルの上方よりの Nd-YAGレーザより の $1064 \mathrm{~nm}$ の近赤外励起光を照射し，180 に散乱したラ マン散乱光を球面ミラーで集光して分光検出器に導く。こ の測定法を用いると, 成熟白内障という濁りと蛍光が極め て強い白内障水晶体汃らも蛍光に妨害されずにきれいな久 ペクトルが測定ができる。

図11 は50才のヒト水晶体の NIR-FTラマンスペクト ルである。眼球破壊という外傷の手術時に, 無傷で得られ た濁りのない正常と思わ机る七ト水晶体である。そのヒト 水晶体の NIR-FT ラマンスペクトルは図40５週筡のラ ットで得られた分散型のラマンスペクトルと同じくらい $\mathrm{S} / \mathrm{N}$ 比もよい。ラットも年を取るとその内部蛍光は増立 てくるが， 5 週齢位では蛍光も少なくき机いなラマンスペ クトルが測定できたわけで，七ト水晶体の NIR-FT ラマ ンスペクトルも同じように各バンドが同定される。

Amide I が 1,672 $\mathrm{cm}^{-1} に$, Amide III が $1,240 \mathrm{~cm}^{-1} に$ 認められる。1,006 $\mathrm{cm}^{-1}$ にフェニールアラニンよりのバン ドが, C-H 変角運動による $1,450 \mathrm{~cm}^{-1}$ のバンドがある。 トリプトファンによる $761 \mathrm{~cm}^{-1}$ と $881 \mathrm{~cm}^{-1}$, チロシンか ら $836 \mathrm{~cm}^{-1}$ と $858 \mathrm{~cm}^{-1}$ にバンドが現われる。 $2,574 \mathrm{~cm}^{-1}$

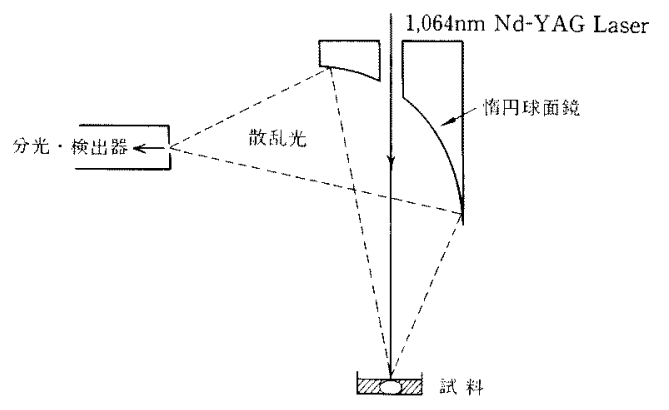

図 10 レーザ照射法とラマン散乱光の集光法
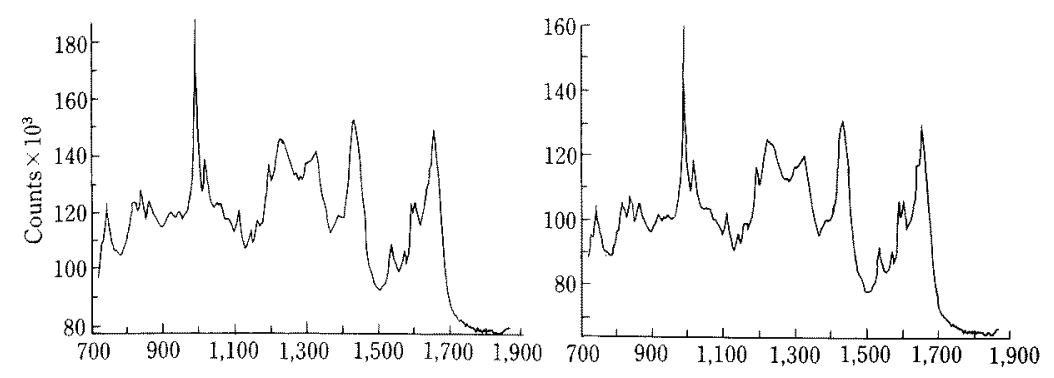

$1 \%$ パラフイルム固定して，16 時間レーザ照射後測定 左は诿明部分，右は白濁した部位からの测定

図 933 才のヒト水晶体からのラマンスペクトル（文献7より） 


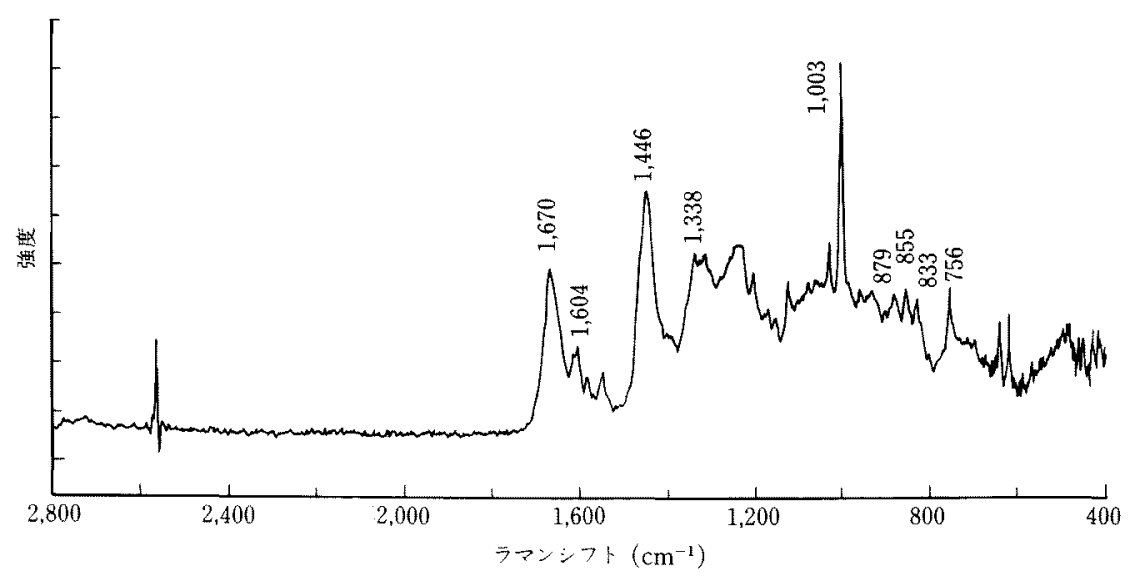

図 1150 才正常水晶体の NIR-FT ラマンスペクトル

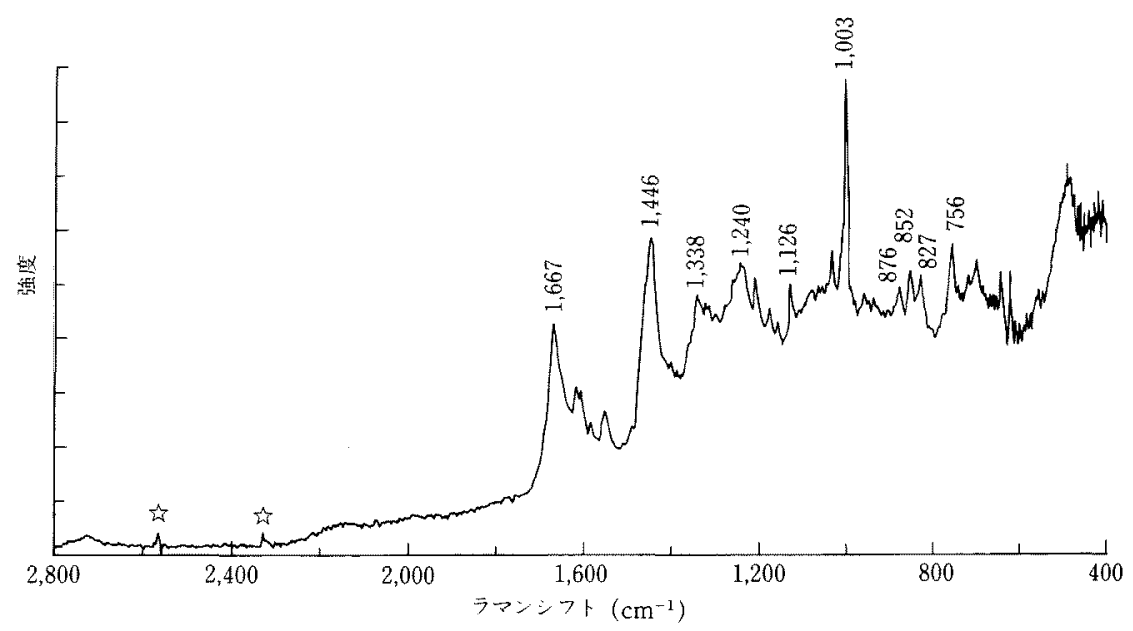

图 1285 才成熟白内障水晶体の NIR-FTラマンスベクトル

には蛋白質の SH 基によるバンドが認められる。

図 12 は8 85 才の成熟白内障といわれる完全に白濁し，さ らに老化と病的のためにかなり濃く褐色の色素が沈着して いるヒト水晶体の NIR-FTラマンスペクトルである。図 11 の正常のヒト水晶体ラマンスペクトルと比べても鮮明 で遜色ない。

\section{4. 角膜, 強膜のラマンスペクトル}

角膜や強膜は, 従来の分散型のラマン分光測定器では測 定しにくかったが，NIR-FTラマン分光法により測定可 能となった

図 13 に家鬼の正常角膜の NIR-FT ラマンスペクトル を示す。1,664 $\mathrm{cm}^{-1} に$ に Amide I, $1,450 \mathrm{~cm}^{-1} に$ はCH の変角運動によるバンド，そして $1,246 \mathrm{~cm}^{-1} に は$ Amide IIIのバンドが現われる。コラーゲンに多いプロリンによる バンドが $858 \mathrm{~cm}^{-1}$ と $917 \mathrm{~cm}^{-1}$ に認められる。ヒドロキシ プロリンによるバンドも $877 \mathrm{~cm}^{-1}$ に認められる。残念な がら $\mathrm{SH}$ 碁により $2,570 \mathrm{~cm}^{-1}$ 付近にはエミッションによる

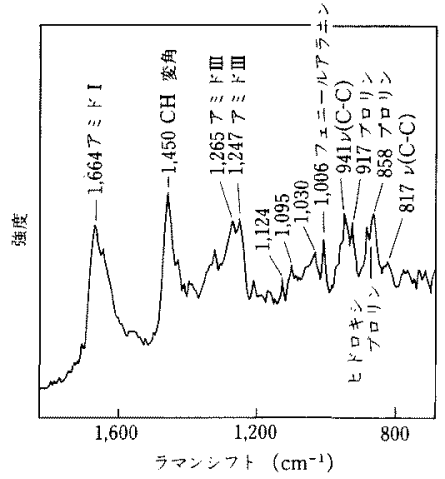

图 13 正常家兔角膜の NIR-FT ラマンスペクトル

ピークが出現しているためバンドとして確認できなかった。 図 14 に強膜のラマンスペクトルを示す。1,664 $\mathrm{cm}^{-1}$ に は Amide I , 1,450 $\mathrm{cm}^{-1}$ には $\mathrm{CH}$ の変角運動によるバン ドそして $1,246 \mathrm{~cm}^{-1}$ には Amide IIIのバンドが現われる。 コラーダンに多いプロリンによるバンドが $858 \mathrm{~cm}^{-1}$ と 
000000000000

$00000000000_{-}^{-30 \mathrm{~m}}$

000000000000

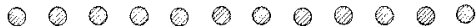

000000000000

00000000000

00000000000

00000000000

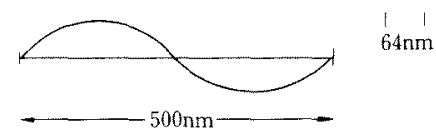

光が角膜を菜通りてきるのは、コラータ゚ン線維が等間隔で並らんでいるの でそれより波長の長い可視光はすり抜ける。

図 14 角膜コラーゲン線維の断面図

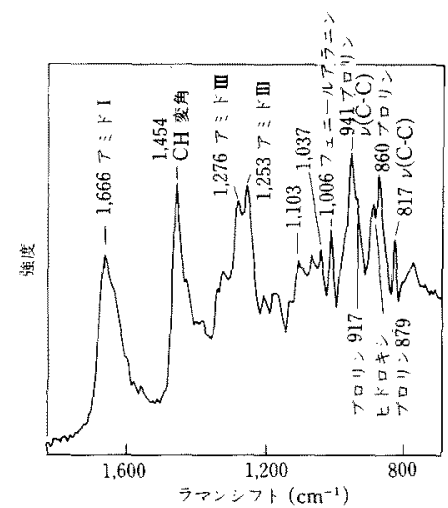

図 15 正常家兔強膜の NIR-FT ラマンスペクトル

$917 \mathrm{~cm}^{-1}$ に認められる。ヒドロキシプロリンによるバン ドも $877 \mathrm{~cm}^{-1}$ に認められる。角膜と強膜のラマンスペク トルが共通のバンドが多いことは，この双方のラマンスペ クトルのもととなる構成成分のI型コラーダンであること による。そのコラーゲンの存在様式は，角膜が透明組織 で，強膜は不透明な組織であることからもうかがえる。角 膜は光をよく通すために，コラーダン線維の並び方がきわ めて秩序上く $64 \mathrm{~nm}$ 間隔で並んでいることによる。その 隙間を水を含むケラタン硫酸，コンドロイチン硫酸などの ムコ多糟類がうめている(図 15)。可視光 (400〜760 $\mathrm{nm}$ ）恃図 15 にあるようにコラーダンの間隔より長いの で，すり抜けることができる。一方不透明な強膜はコラー ゲン線維がアトランダムに，そして角膜より密に扔りかさ なっている。

角膜はアルカリなどの化学腐食をうけたあと，その傷を 修復しようとしてコラーゲン線維を再生させる。そのとき 傷が深いと図 15 にあるようにきれいに再生できず強膜の ように線維の並ぎがアトランダムになってしまう。それを 角膜白斑というが，図16 は家兔角膜にアルカリ腐食で潰

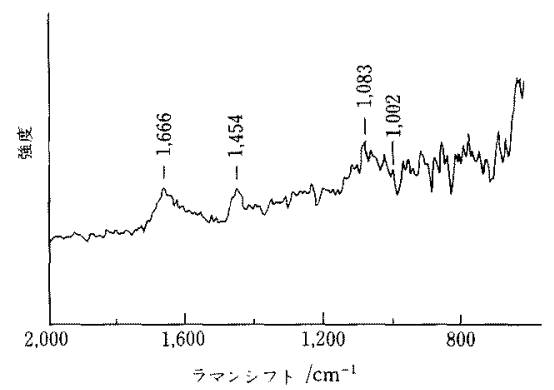

图 16 アルカリ腐食!逗關後の角膜白斑の NIR-FT ラマンスペクトル

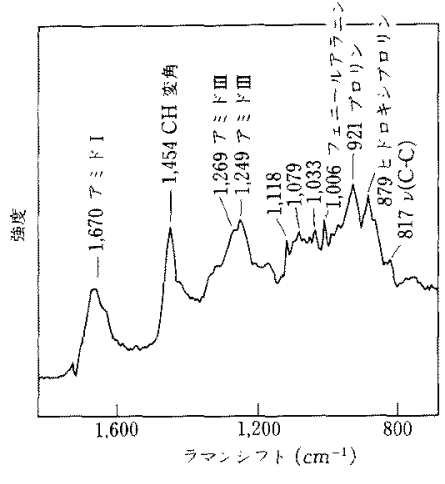

乾蜗したコラーゲン線維より值接淸定

図 17 精製したヒトコラーゲンI 型の NIR-FT ラマンスペスクトル

瘍をつくって一週間目の角膜白斑の NIR-FT ラマンスペ クトルである。ノイズがつよいスペクトルであって，知り たいプロりンなどはっきりしないが，アミドIや $\mathrm{CH}_{2}$ 変 角振動によるバンドが観察される。現在実験を継続してい るところである。

ヒトコラーゲンI 型のラマンスペクトルを図 17 に示す。 1,670 $\mathrm{cm}^{-1}$ には Amide I , 1,454 $\mathrm{cm}^{-1}$ には CH の変角運 動によるバンド，そして 1,269 と $1,249 \mathrm{~cm}^{-1}$ には Amide IIIのバンドが現われる。コラーダンに多いプロリンによる バンドが $921 \mathrm{~cm}^{-1}$ に認められる。しかし， $858 \mathrm{~cm}^{-1}$ にあ るプロリンのバンドは小さなショルダとしてしか認められ ない。ヒドロキシンプロリンによるバンドも $879 \mathrm{~cm}^{-1} に$ 認められる。基本的には似ているが，この精製したヒトコ ラーゲンI型は水分を含まない乾燥したものから直接ラマ ン測定しているので，生体にある水分を十分に含んだ形の コラーゲンとは存在様式が違うために，ラマンスペクトル の違いとして現われていることが考党られる(9)。

\section{5. 視神経のラマンスペクトル}

視神経は神経細胞の束に尾崎の総説中の大脳の白質，す 


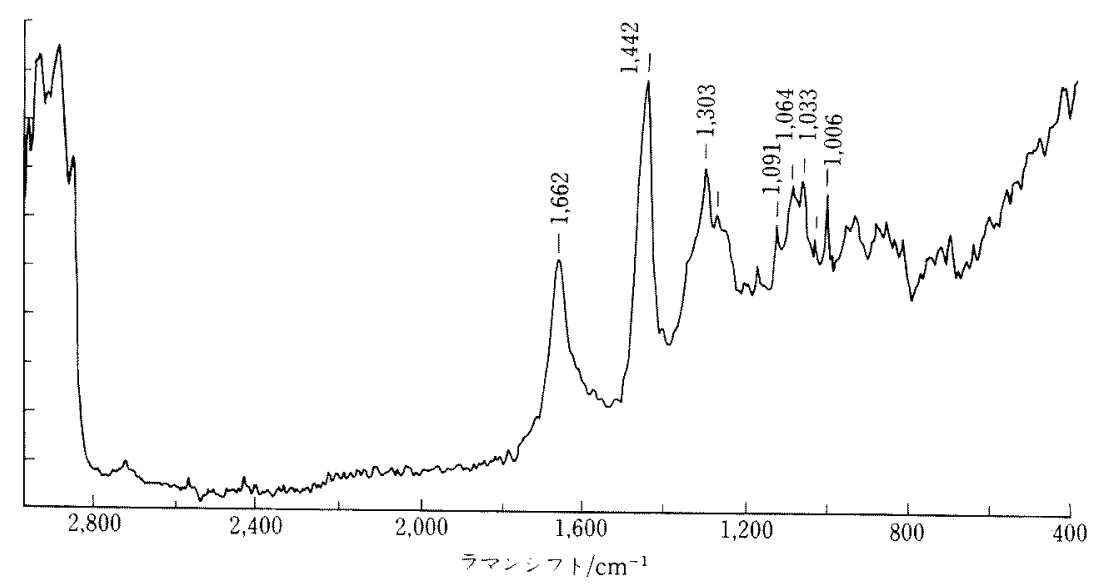

図 18 家兔視神経の NIR-FT ラマンスペクトル

なわち神経線維の多い部分のラマンスペクトルに似てい $3^{(1)(10)}$ 。図 18 に家鬼の視神経の NHR-FT ラマンスペク トルを示す。ピークとして現われるバンドは, 主として視

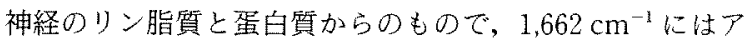
ミド】によるバンド, $1,006 \mathrm{~cm}^{-1}$ にはフニールアラニン のピークが現われ，主に蛋白質によるものである。1,303， 1,091，1,064，1,033 $\mathrm{cm}^{-1}$ にあらわれるバンドは主にリン 脂質によるものである。1,442 $\mathrm{cm}^{-1} に \mathrm{CH}_{2}$ の変角振動に よるバンドが現われ，これはりン脂質と蛋白質の $\mathrm{CH}_{2}$ 変 角振動による。アミドIのバンドが蛋白質より, $\mathrm{CH}_{2}$ 変 角振動による $1,442 \mathrm{~cm}^{-1}$ のバンドが蛋白質と脂質よりも たらすことにより，二つのバンドの強度比は蛋白質と脂質 の含量を表す目安，すな⿰力口古，神経細胞集団が多い灰白質 （皮質）か，神経線維が多い白質かといった区別をつける マーカとなる(10)。視神経のスペクトルを比較すると，本 質的に神経線維の多い白質のスペクトルであるが，白質よ りも蛋白質濃度がやや高いことがかかる（前揭の総説の図 1 参照 $)^{(1)(10)}$ 。

\section{8. 将来の展望}

ラマン分光法の利点の一つは, 複雑な生体組織を破壊す ることなくそのままの状態で, 分子レベルの情報が的確に 得られることである。この利点を生かすには被験者の生体 組織にレーザ光を当て, 直接散乱してきたラマン散乱光を 測定できることが望ましい。被験者を分光器の試料室に入 机るのでなく，レーザ光を光ファイバで導き，目的とする 組織に当て，またラマン散乱光をうまく集光し光ファイバ で分光検出器に導く方法が考えられる。

眼はその性質状露出している部分も多い。また透明組織 を通して光を当て，また散乱光を集光することができる。 角膜は直接, 強膜以薄い結膜を通して直接測定できる。水 晶体は透明である角膜と房水を通して測定可能である。外 科的な操作ができれば眼の奥にある視神経からも測定可能 となるであろう。

ここで紹介した近赤外レーザで励起するラマン分光法は
いますぐにでも，上卜角膜には応用できるところまできて いる(測定時間をもっともっと短くしないと被験者はじっ としていられないだろうが，アルカりによる角膜白斑だ けでなく，先天代謝異常症で角膜に異常物質が沈着した り，角膜そのものが遺伝的に打かしくなる角膜变性症など がある。そういった沈着下異常物質や変性簓所を解析する ために，破壊的にサンプルをとらずに，ラマンスペクトル だけで直接に診断をつけられる可能性がある。レーザ，光 ファイバ, 分光器, 検出器の発達は急速に進んでおり, 臨床 応用人の基礎的データの蓄積と解析が重要となってきている。 (平成 6 年 4 月 11 日受付)

\section{文献}

（1）娓畸幸洋：「生体レーザラマン」, 電学諭 C 114, 5, 508 (平 6)

（2）水野有武：「水昆体のラマン分光学!，病腿生理 9：164(平 2)

（3）宮崎仁志・水野有武：「ラット水晶体の部位にみたラマンスペク トル」目眼誌 $91: 437$ (眧 62)

(4) Y. Ozaki, A. Mizuno, K. Itoh \& K. Iriyama: "Inter-and Intramolecular disulfice bond formation and related structural changes in the lens proteins" J. Biol. Chem, 262: 5545 (1987)

(5) K. Itoh, Y. Ozaki, A. Mizuno \& K. Iriyama: "Structural changes in the lens proteins of hereditary cataracts monitored by Raman spectroscopy", Biochemistry, 22 : 1773 (1983)

(6) N. T. Yu, M. Bando \& I. F. R. Kuck Jr: "Fluorescence/ Raman intensity radio for monitoring the psthologic state of human lens", Invest. Ophthalmol, Vis. Sci. 26-97, (1985)

( 7 G. Gijsbers, G. Vrensen, B. Willekens, D. Maatman, F. De Mul \& J. Greve: "Raman microspectroscopic investigation of human eye lenses", Laser Scattering Spectroscopy of Biological Objects p. 583-94, (1986) Elsevier, Prague.

（8）尾崎幸洋・水野有武：[近赤外动起フーリ工変換ラマン分光法に 上方非破境生体計測」，応用物理 $61: 596$ (平 4)

(9) A. Mizuno, M. Tsuji, K. Fujii, K. Kawauchi \& Y. Ozuki "Near-infrared Fourier Transform Raman spectroscopic study of cornea and sclera", Jpn. J. Ophthalmol. 38: 44 (1994)

(10) A. Mizuno, T. Hayashi, K. Tashibu, S. Muraishi, K. Kawauchi \& Y. Ozaki: "Nearinfrared FT-Raman spectra of the rat brain tissues", Neurosci. Lett, 141: 47 (1992)

水 野 有 武 1969 年慈惠医科大学卒業。現在, 慈患医科大学化 学教室助教授・眼科萧任講師。医学博士。眼と神経の生化学, ラマン 分光学などの研焭に従事。 